\title{
A novel approach to comparing simultaneous size-segregated particulate matter (PM) concentration ratios by means of a dedicated triangular diagram using the Agri Valley PM measurements as an example
}

\author{
A. Speranza ${ }^{1}$, R. Caggiano ${ }^{1}$, S. Margiotta ${ }^{1,2}$, and S. Trippetta ${ }^{1,2}$ \\ ${ }^{1}$ IMAA, Istituto di Metodologie per l'Analisi Ambientale, CNR, 85050 Tito Scalo, PZ, Italy \\ ${ }^{2}$ Osservatorio Ambientale Val d'Agri, Via Vittorio Emanuele II, 3, 85052 Marsico Nuovo, PZ, Italy
}

Correspondence to: A. Speranza (antonio.speranza@imaa.cnr.it)

Received: 28 February 2014 - Published in Nat. Hazards Earth Syst. Sci. Discuss.: 3 June 2014

Revised: 7 August 2014 - Accepted: 12 August 2014 - Published: 8 October 2014

\begin{abstract}
This work presents a novel approach to comparing and graphically representing simultaneous concentration measurements of $\mathrm{PM}_{10}, \mathrm{PM}_{2.5}$ and $\mathrm{PM}_{1}$ (i.e., aerosol particles with aerodynamic diameters less than $10,2.5$ and $1 \mu \mathrm{m}$, respectively) with similar data reported in the literature using $\mathrm{PM}_{2.5} / \mathrm{PM}_{10}$ and $\mathrm{PM}_{1} / \mathrm{PM}_{10}$ concentration ratios. With this aim, a dedicated triangular diagram was used. The proposed approach was applied to size-segregated particulate matter (PM) concentrations recorded in the Agri Valley (Basilicata region - southern Italy). Results show that the $\mathrm{PM}_{10}, \mathrm{PM}_{2.5}$ and $\mathrm{PM}_{1}$ concentrations recorded in the Agri Valley are comparable both in terms of PM concentration ratios and PM levels to an urban site.
\end{abstract}

\section{Introduction}

The growing interest aroused by aerosol particles (also referred to as particulate matter, PM) is due to their impact on human health, air quality and global climate change (Colette et al., 2008; IPCC, 2007; WHO, 2006). These particles can differ in size, shape and chemical composition, and can be generated both from natural and/or anthropic sources. The particle size fraction is an important physical parameter, since it can provide information relating to the particle origin, its formation process and its effects on human health. In fact, the PM coarse fraction (i.e., $\mathrm{PM}_{10}$, aerosol particles with aerodynamic diameters less than $10 \mu \mathrm{m}$ ) mainly originates from natural sources such as re-suspension of local soil by winds, desert dust, forest fire, volcanic eruptions (Aleksandropoulou and Lazaridis, 2013; Campos-Ramos et al., 2011), as well as anthropogenic sources such as re-suspension of road dust, material grinding and crushing (Colbeck, 2008; Van Dingenen et al., 2004). Regarding fine and ultrafine fractions (i.e., $\mathrm{PM}_{2.5}$ and $\mathrm{PM}_{1}$, aerosol particles with aerodynamic diameters less than 2.5 and $1 \mu \mathrm{m}$, respectively), they mainly originate from anthropic sources such as industrial activities, traffic, and domestic heating (Caggiano et al., 2010; Lin and Lee, 2004). According to the particle size, PM can pose risks to human health because of its adverse effects on both the respiratory and cardiovascular systems (Pope III and Dockery, 2006). In fact, coarse particles are likely to be deposited in the extra-thoracic and upper bronchial regions. Instead, fine and ultrafine particles may travel deeply into the lungs and may be deposited in the lower bronchial and alveolar regions.

In the light of this, several efforts have been made in order to obtain simultaneous concentration measurements of different PM fractions (Massey et al., 2012; Cabada et al., 2004), and their ratios have been used to obtain preliminary indications of the sources contributing to the presence of the PM in the local atmosphere (Pérez et al., 2010; Cheng et al., 2006; Vecchi et al., 2004), and/or to compare the PM levels between different sites (Shahsavani et al., 2012; Gomišček et al., 2004; Li and Lin, 2002; Claiborn et al., 2000).

This work presents a novel approach to comparing and graphically representing simultaneous measurements of $\mathrm{PM}_{10}, \mathrm{PM}_{2.5}$ and $\mathrm{PM}_{1}$ concentrations with similar data 


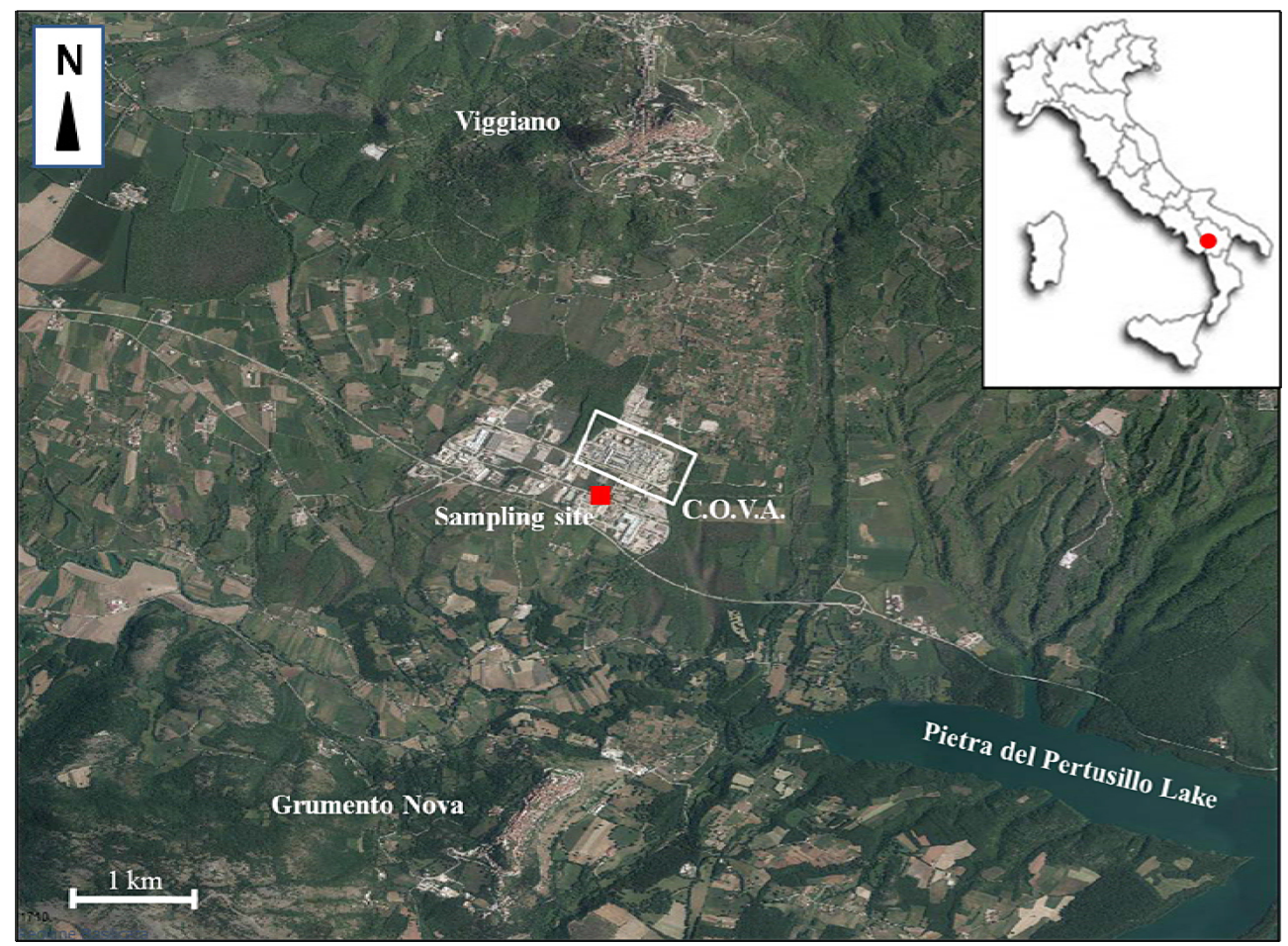

Figure 1. COVA plant and PM sampling site location. Copyright AGEA - Orthophoto 2011.

reported in the literature using both $\mathrm{PM}_{2.5} / \mathrm{PM}_{10}$ and $\mathrm{PM}_{1} / \mathrm{PM}_{10}$ concentration ratios. With this aim, a dedicated triangular diagram was used. The proposed approach was applied using PM concentration measurements (Trippetta et al., 2013) recorded in the Agri Valley (Basilicata region - southern Italy). This area was chosen since it is an area of great environmental concern. In fact, the Agri Valley houses the largest European onshore reservoir (crude oil and gas) and the biggest oil/gas pre-treatment plant, identified as the Centro Olio Val d'Agri (COVA) in a rural/anthropized context (Fig. 1). The COVA plant produces continuous gaseous and particulate atmospheric emissions that could give rise to a wide range of environmental and human health impacts due to the large presence of cultivated and grazing areas and several small towns (from 1700 to 5400 inhabitants) in its surroundings.

\section{Methodology}

The triangular diagram, based on Sneed and Folk's original idea (Sneed and Folk, 1958) and generally applied in pebbles and fabric shapes (Benn, 1994; Illenberger, 1991), has been opportunely arranged both to compare and graphically represent simultaneous $\mathrm{PM}_{10}, \mathrm{PM}_{2.5}$ and $\mathrm{PM}_{1}$ concentration ratios measured at a reference site with similar measurements reported in the literature.

This approach is based on the calculation of the ratios between $\mathrm{PM}_{2.5}$ and $\mathrm{PM}_{10}$ concentrations (i.e., $\mathrm{PM}_{2.5} / \mathrm{PM}_{10}$, that is, the fine fraction contribution to the $\mathrm{PM}_{10}$ ), between $\mathrm{PM}_{1}$ and $\mathrm{PM}_{10}$ concentrations (i.e., $\mathrm{PM}_{1} / \mathrm{PM}_{10}$, that is, the ultrafine fraction contribution to the $\mathrm{PM}_{10}$ ), and their representation by means of a dedicated software package (Graham and Midgley, 2000).

The particular features of this diagram also allow the representation of $\mathrm{PM}_{1} / \mathrm{PM}_{2.5}$ and the $\left(\mathrm{PM}_{2.5}-\mathrm{PM}_{1}\right) /\left(\mathrm{PM}_{10}-\mathrm{PM}_{1}\right)$ concentration ratios. In particular, the former identifies the contribution of the ultrafine fraction to the fine fraction. The latter represents the proportion between the intermodal and coarse fractions.

Each site will be identified in the diagram with a point representing the corresponding size-segregated PM concentration ratios. Two data points in the triangular diagram (e.g., $P_{\mathrm{a}}$ and $P_{\mathrm{b}}$ ) can be considered closed if they have $\mathrm{PM}_{1 \mathrm{a}} / \mathrm{PM}_{10 \mathrm{a}} \approx \mathrm{PM}_{1 \mathrm{~b}} / \mathrm{PM}_{10 \mathrm{~b}}$ as well as $\mathrm{PM}_{2.5 \mathrm{a}} / \mathrm{PM}_{10 \mathrm{a}} \approx \mathrm{PM}_{2.5 \mathrm{~b}} / \mathrm{PM}_{10 \mathrm{~b}}$ within an acceptable tolerance. As a consequence, it is also valid that $\left(\mathrm{PM}_{2.5 \mathrm{a}}-\mathrm{PM}_{1 \mathrm{a}}\right) /\left(\mathrm{PM}_{10 \mathrm{a}}-\mathrm{PM}_{1 \mathrm{a}}\right) \approx\left(\mathrm{PM}_{2.5 \mathrm{~b}}-\mathrm{PM}_{1 \mathrm{~b}}\right) /$ $\left(\mathrm{PM}_{10 \mathrm{~b}}-\mathrm{PM}_{1 \mathrm{~b}}\right)$ and that $\mathrm{PM}_{1 \mathrm{a}} / \mathrm{PM}_{2.5 \mathrm{a}} \approx \mathrm{PM}_{1 \mathrm{~b}} / \mathrm{PM}_{2.5 \mathrm{~b}}$. Therefore, comparing simultaneous sampling of PM in the triangular diagram enables a comparison of the ratios between the mass concentrations of $\mathrm{PM}$ (i.e., $\mathrm{PM}_{1} / \mathrm{PM}_{10}$, $\mathrm{PM}_{2.5} / \mathrm{PM}_{10},\left(\mathrm{PM}_{2.5}-\mathrm{PM}_{1}\right) /\left(\mathrm{PM}_{10}-\mathrm{PM}_{1}\right)$ and $\mathrm{PM}_{1} /$ $\mathrm{PM}_{2.5}$ ) all together.

A site is considered similar to the reference one in terms of $\mathrm{PM}$ ratios if the corresponding $\mathrm{PM}_{2.5} / \mathrm{PM}_{10}$ and $\mathrm{PM}_{1} / \mathrm{PM}_{10}$ concentration ratios differ by no more than $\pm 5 \%$. The 


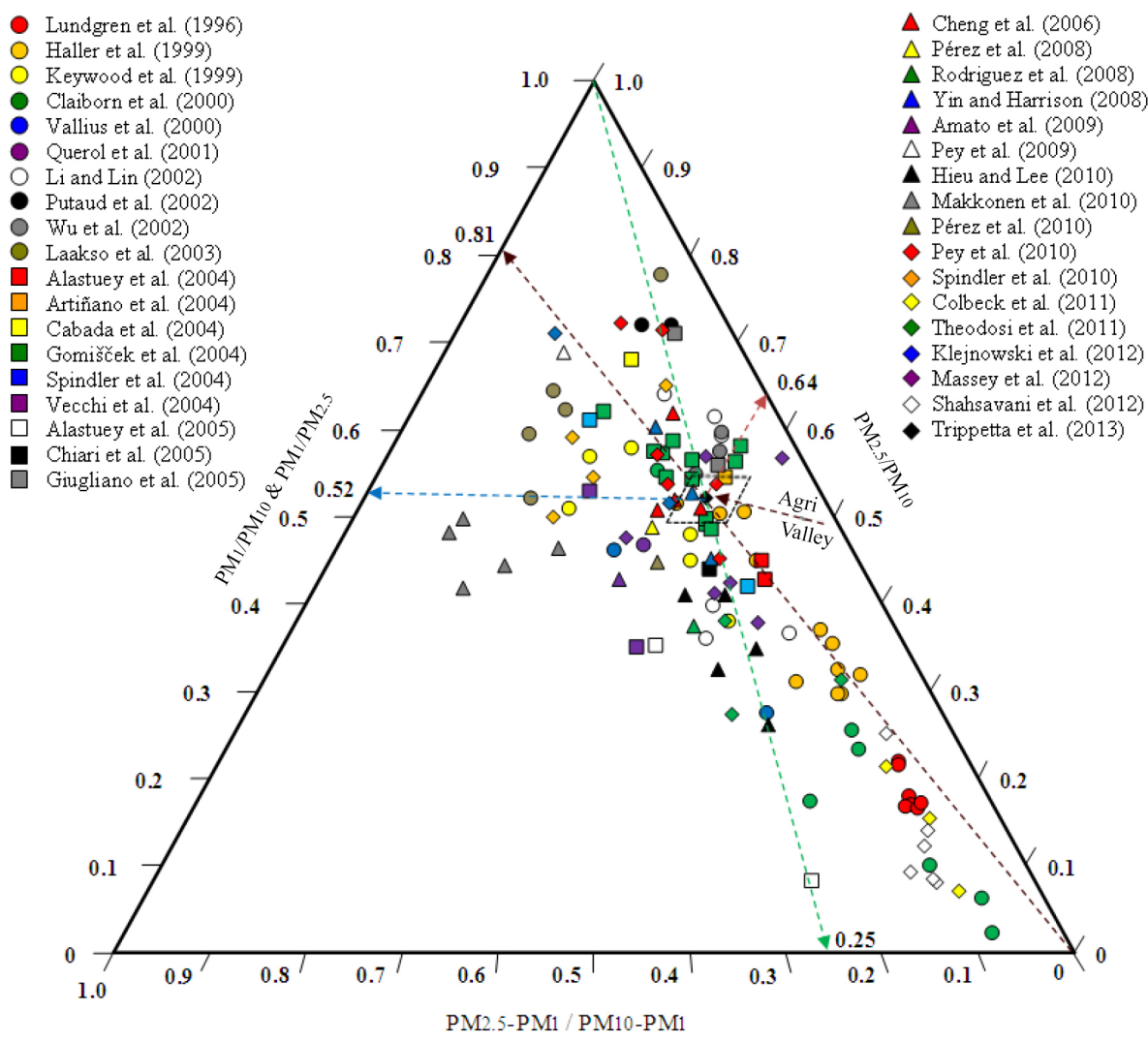

Figure 2. Triangular diagram for the $\mathrm{PM}_{1} / \mathrm{PM}_{10}, \mathrm{PM}_{2.5} / \mathrm{PM}_{10}, \mathrm{PM}_{1} / \mathrm{PM}_{2.5}$ and $\left(\mathrm{PM}_{2.5}-\mathrm{PM}_{1}\right) /\left(\mathrm{PM}_{10}-\mathrm{PM}_{1}\right)$ concentration ratios.

uncertainty for the $\mathrm{PM}_{1} / \mathrm{PM}_{10}$ and of $\mathrm{PM}_{2.5} / \mathrm{PM}_{10}$ concentration ratios has been evaluated from the data reported in Trippetta et al. (2013). The combined uncertainty has been taken into account for $A=B / C$ :

$$
\begin{aligned}
& \frac{\delta_{\mathrm{a}}}{A}=\sqrt{\left(\frac{\delta_{\mathrm{b}}}{B}\right)^{2}+\left(\frac{\delta_{\mathrm{c}}}{C}\right)^{2}}, \\
& \delta_{x}=\frac{s_{x}}{\sqrt{n}}(x=a, b, c),
\end{aligned}
$$

(Bell, 1999). The uncertainty is within $5 \%$.

It is important to observe that, for comparison purposes, close values of $\mathrm{PM}_{1} / \mathrm{PM}_{10}, \mathrm{PM}_{2.5} / \mathrm{PM}_{10}, \mathrm{PM}_{1} / \mathrm{PM}_{2.5}$ and $\mathrm{PM}_{2.5}-\mathrm{PM}_{1} / \mathrm{PM}_{10}-\mathrm{PM}_{1}$ do not necessarily mean close values of $\mathrm{PM}_{1}, \mathrm{PM}_{2.5}$ and $\mathrm{PM}_{10}$ concentrations. Indeed, if two close points (e.g., $P_{\mathrm{a}}$ and $P_{\mathrm{b}}$ ) displayed in the triangular diagrams are considered, they have similar values of the respective ratios $\mathrm{PM}_{1 \mathrm{a}} / \mathrm{PM}_{10 \mathrm{a}} \approx \mathrm{PM}_{1 \mathrm{~b}} / \mathrm{PM}_{10 \mathrm{~b}}$ and $\mathrm{PM}_{2.5 \mathrm{a}} / \mathrm{PM}_{10 \mathrm{a}} \approx \mathrm{PM}_{2.5 \mathrm{~b}} / \mathrm{PM}_{10 \mathrm{~b}}$, etc. Nevertheless, the concentration value of $\mathrm{PM}_{1 \mathrm{a}}$ can be different from that of $\mathrm{PM}_{1 \mathrm{~b}}$, and the concentration value of $\mathrm{PM}_{2.5 \mathrm{a}}$ can be different from that of $\mathrm{PM}_{2.5 \mathrm{~b}}$. Hence, only if close points have $\mathrm{PM}_{10 \mathrm{a}}$ concentration $\approx \mathrm{PM}_{10 \mathrm{~b}}$ concentration, then $\mathrm{PM}_{1 \mathrm{a}}$ concentration $\approx \mathrm{PM}_{1 \mathrm{~b}}$ concentration and $\mathrm{PM}_{2.5 a}$ concentration $\approx \mathrm{PM}_{2.5 \mathrm{~b}}$ concentration.
In order to refine the comparison and to identify all the sites that are also characterized by $\mathrm{PM}_{10}, \mathrm{PM}_{2.5}$ and $\mathrm{PM}_{1}$ concentrations similar to those measured at the reference site, the points previously identified in the diagram are further categorized according to the corresponding $\mathrm{PM}_{10}$ concentration values. In particular, the $\mathrm{PM}_{10}$ concentration values are grouped into eleven classes. The first ten classes vary from 0 to $50 \mathrm{\mu g} \mathrm{m}^{-3}$, using a step of $5 \mathrm{\mu g} \mathrm{m}^{-3}$. The last class includes all the $\mathrm{PM}_{10}$ concentration values higher than $50 \mu \mathrm{g} \mathrm{m}^{-3}$.

\section{Results and discussion}

In order to compare the Agri Valley data with respect to simultaneous PM measurements reported in the literature, both $\mathrm{PM}_{2.5} / \mathrm{PM}_{10}$ and $\mathrm{PM}_{1} / \mathrm{PM}_{10}$ concentration ratios were utilized.

The triangular diagram (Fig. 2) points out that PM concentration ratios calculated for the Agri Valley, i.e., $\mathrm{PM}_{2.5} / \mathrm{PM}_{10}=0.64$ and $\mathrm{PM}_{1} / \mathrm{PM}_{10}=0.52$, are close to the PM concentration ratios calculated for residential environments in Spokane (Haller et al., 1999), urban environments in Vienna (Gomišček et al., 2004), industrial environments in Linz (Gomišček et al., 2004), roadside environments in Hong Kong (Cheng et al., 2006), 
urban background environments in Birmingham (Yin and Harrison, 2008), and urban environments in Barcelona (Pey et al., 2010). In fact, all these sampling sites show $\mathrm{PM}_{2.5} / \mathrm{PM}_{10}$ and $\mathrm{PM}_{1} / \mathrm{PM}_{10}$ concentration ratios included in ranges of $0.64 \pm 0.032$ and $0.52 \pm 0.026$, respectively. Moreover, regarding the ultrafine fraction, $\mathrm{PM}_{1} / \mathrm{PM}_{2.5} \geq 0.5$ highlights the fact that its contribution to the fine fraction is not negligible. This last result is shown for almost all the $\mathrm{PM}_{1} / \mathrm{PM}_{2.5}$ concentration ratios considered.

Taking again into account the $\mathrm{PM}_{2.5} / \mathrm{PM}_{10}$ and $\mathrm{PM}_{1} / \mathrm{PM}_{10}$ concentration ratios found in the $\pm 5 \%$ range, and also considering the sampling season, the results show that the Agri Valley PM concentrations ratios are comparable with those calculated by Gomišček et al. (2004) and Cheng et al. (2006) during the summer season, and accordingly with the Agri Valley measurements collected mainly during the warm period.

The $\mathrm{PM}_{2.5} / \mathrm{PM}_{10}$ and $\mathrm{PM}_{1} / \mathrm{PM}_{10}$ concentration ratios observed for the Agri Valley are plotted in a segment of the triangular diagram where it is possible to find most of the $\mathrm{PM}_{2.5} / \mathrm{PM}_{10}$ and $\mathrm{PM}_{1} / \mathrm{PM}_{10}$ concentration ratios calculated for urban sites referring to large cities such as Barcelona, Vienna, Athens, Birmingham, Milan, Madrid, and Helsinki, among others (Theodosi et al., 2011; Pérez et al., 2008, 2010; Pey et al., 2010; Amato et al., 2009; Rodríguez et al., 2008; Yin and Harrison, 2008; Cheng et al., 2006; Giugliano et al., 2005; Artiñano et al., 2004; Vecchi et al., 2004; Gomišček et al., 2004; Li and Lin, 2002; Vallius et al., 2000), as well as to sites characterized by vehicular traffic and construction/industrial emissions (Klejnowski et al., 2012; Massey et al., 2012; Hieu and Lee, 2010; Pey et al., 2009; Gomišček et al., 2004; Li and Lin, 2002; Wu et al., 2002; Querol et al., 2001), despite them not all being included in the $5 \%$ range. Furthermore, in this segment of the triangular diagram, the fine fraction is predominant with respect to the coarse fraction, with $\mathrm{PM}_{2.5} / \mathrm{PM}_{10}$ concentration ratios ranging from about 0.5 to 0.7 . Instead, $\mathrm{PM}_{1} / \mathrm{PM}_{10}$ can range from about 0.6 to 0.3 . Moreover, the intermodal size fraction is always lower than the coarse fraction, i.e., the $\mathrm{PM}_{2.5}-\mathrm{PM}_{1} / \mathrm{PM}_{10}-\mathrm{PM}_{1}$ ratio is below 0.5 .

In addition, the comparison of the Agri Valley data with respect to simultaneous PM measurements reported in the literature can be further extended to all those sites whose $\mathrm{PM}_{1} / \mathrm{PM}_{2.5}$ and $\mathrm{PM}_{1} / \mathrm{PM}_{10}$ concentration ratios plus their uncertainties partially overlap the ranges $\mathrm{PM}_{1} / \mathrm{PM}_{2.5}=0.64 \pm 0.032$ and $\mathrm{PM}_{1} / \mathrm{PM}_{10}=0.52 \pm 0.026$ in the triangular diagram. Within this framework, as a first step, the sites to be compared, considering also the season of sampling (warmer period) in the Agri Valley, are the industrial environment in Linz, the urban environment in Graz (Gomišček et al., 2004), and the residential site in Spokane (Haller et al., 1999).

This comparison considers a larger data set. Again, this shows that the Agri Valley PM concentration ratios are com- parable with PM concentration ratios calculated for urban sites.

The triangular diagram also shows that both the $\mathrm{PM}_{2.5} / \mathrm{PM}_{10}$ and $\mathrm{PM}_{1} / \mathrm{PM}_{10}$ concentration ratios recorded for the Agri Valley are different from those calculated for rural and semirural sites (Spindler et al., 2004, 2010; Yin and Harrison, 2008; Laakso et al., 2003; Putaud et al., 2002). The PM concentration ratios calculated for these sites fall into a segment of the diagram characterized by values of the $\mathrm{PM}_{1} / \mathrm{PM}_{10}$ ratio above 0.5 as well as high values of the $\mathrm{PM}_{2.5} / \mathrm{PM}_{10}$ concentration ratio, which are above 0.7 , with some exceptions for Gomišcek et al. (2004) and Spindler et al. (2004). Therefore, in this segment, the fine fraction and the ultrafine fraction are predominant over the coarse fraction, while the intermodal fraction is comparable with the coarse fraction. In fact, the $\mathrm{PM}_{2.5}-\mathrm{PM}_{1} / \mathrm{PM}_{10}-\mathrm{PM}_{1}$ concentration ratio observed can reach values above 0.5 .

As Fig. 2 shows, the Agri Valley $\mathrm{PM}_{2.5} / \mathrm{PM}_{10}$ and $\mathrm{PM}_{1} / \mathrm{PM}_{10}$ concentration ratios are also quite different from those calculated for arid sites (Shahsavani et al., 2012; Lundgren et al., 1996), for sites affected both by dust storm originating in Asia (Claiborn et al., 2000) and strong African dust outbreak episodes (Alastuey et al., 2005), and dusty roads (Colbeck et al., 2011). In fact, the PM concentration ratios calculated for these sites are plotted towards the right lower vertex of the triangular diagram, where $\mathrm{PM}_{2.5} / \mathrm{PM}_{10}$ and $\mathrm{PM}_{1} / \mathrm{PM}_{10}$ are below 0.5. Therefore, in this segment, the coarse fraction is predominant with respect to the fine fraction and the ultrafine fraction. The intermodal fraction compared to the coarse fraction is found to be very low. In fact, the $\mathrm{PM}_{2.5}-\mathrm{PM}_{1} / \mathrm{PM}_{10}-\mathrm{PM}_{1}$ ratios are in a range between about 0.1 and 0.3 .

In order to identify all the sites with similar $\mathrm{PM}_{1}, \mathrm{PM}_{2.5}$ and $\mathrm{PM}_{10}$ concentrations, the $\mathrm{PM}_{10}$ concentrations reported by the selected studies were grouped into eleven ranges. By considering the PM concentration of the sites whose $\mathrm{PM}_{2.5} / \mathrm{PM}_{10}$ and $\mathrm{PM}_{1} / \mathrm{PM}_{10}$ concentration ratios differ by no more than $\pm 5 \%$ from the corresponding ratios calculated for the Agri Valley, the values of $\mathrm{PM}_{1}, \mathrm{PM}_{2.5}$ and $\mathrm{PM}_{10}$ concentrations recorded in the Agri Valley (11.0, 13.6 and $21.2 \mu \mathrm{g} \mathrm{m}^{-3}$, respectively) are comparable with the $\mathrm{PM}_{1}$, $\mathrm{PM}_{2.5}$ and $\mathrm{PM}_{10}$ concentrations measured in Vienna (14.2, 17.5 and $26.1 \mu \mathrm{g} \mathrm{m}^{-3}$, respectively), but they are quite different from those measured in Hong Kong (56.3, 71.0 and $110.3 \mu \mathrm{g} \mathrm{m}^{-3}$, respectively) (Fig. 3). In conclusion, by considering $\mathrm{PM}_{2.5} / \mathrm{PM}_{10}$ and $\mathrm{PM}_{1} / \mathrm{PM}_{10}$ concentration ratios, the PM concentrations measured in the Agri Valley are comparable with those reported in Gomišček et al. (2004).

Finally, the Agri Valley data (i.e., the $\mathrm{PM}_{1} / \mathrm{PM}_{10}$ and $\mathrm{PM}_{2.5} / \mathrm{PM}_{10}$ concentration ratios) are placed toward the upper part of the segment, where most of the data from urban sites can be found, next to the segment where most of the rural measurements are plotted, and far away from the data recorded at arid sites. Nevertheless, the contributions of the anthropogenic emissions are such that the data recorded are 


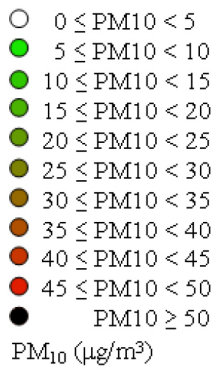

.

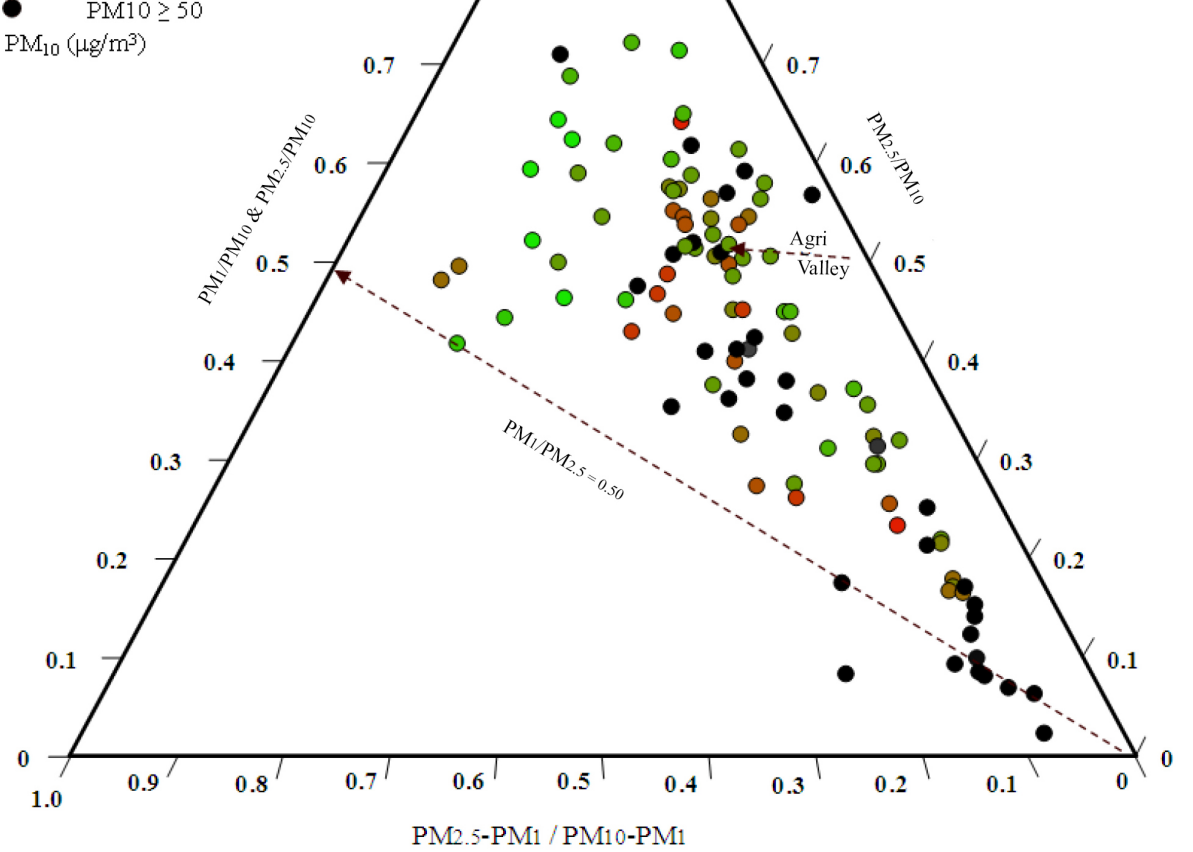

Figure 3. The triangular diagram of $\mathrm{PM}$ concentration ratios further categorized according to the $\mathrm{PM}_{10}$ concentrations. The line in the center of the triangular diagram represents a $\mathrm{PM}_{1} / \mathrm{PM}_{2.5}$ concentration ratio of 0.5 .

very much comparable to those recorded at a typically urban site. All these results may be explained by considering the peculiarity of the area under study, and they are consistent with the emissions features of rural areas, where anthropogenic activities typical of small urban settlements and industrial plants processing oil/gas can be found.

\section{Conclusions}

A novel approach based on the use of a modified version of Sneed and Folk's triangular diagram was proposed and used to compare and graphically represent simultaneous measurements of $\mathrm{PM}_{10}, \mathrm{PM}_{2.5}$ and $\mathrm{PM}_{1}$ concentrations recorded in the Agri Valley with similar measurements reported in the literature. With this aim, $\mathrm{PM}_{1} / \mathrm{PM}_{10}$ and $\mathrm{PM}_{2.5} / \mathrm{PM}_{10}$ concentration ratios were used. Focusing on the $\mathrm{PM}_{2.5} / \mathrm{PM}_{10}$ and $\mathrm{PM}_{1} / \mathrm{PM}_{10}$ concentration ratios reported for the Agri Valley, they are plotted in an segment of the triangular diagram where it is possible to find most of the $\mathrm{PM}_{2.5} / \mathrm{PM}_{10}$ and $\mathrm{PM}_{1} / \mathrm{PM}_{10}$ concentration ratios calculated for urban sites. Moreover, the Agri Valley $\mathrm{PM}_{2.5} / \mathrm{PM}_{10}$ and $\mathrm{PM}_{1} / \mathrm{PM}_{10}$ concentration ratios are both different from those reported for rural and semirural sites, and quite different from those referring to arid sites or sites affected by dust storms. Using $\mathrm{PM}_{10}$ concentration data, the results are that, among the identified urban environments, the values of $\mathrm{PM}_{1}, \mathrm{PM}_{2.5}$ and $\mathrm{PM}_{10}$ concentrations measured in the Agri Valley are comparable with those recorded in Vienna.

Therefore, even though the Agri Valley is an area mainly characterized by rural features, the presence of anthropogenic activities such as the oil/gas pre-treatment plant makes this area comparable to an urban site both in terms of PM concentration ratios and PM levels.

In conclusion, this work shows that the suggested approach allows a simple and clear identification of sites with comparable atmospheric PM concentrations.

As future work, the proposed approach could be used to evaluate both how the PM concentration ratios can depend on the seasons of sampling and to assess the predominance of a size fraction with another one. Moreover, in the future, the diagram could be used to compare the PM concentration ratios, refining the data with respect to the climate conditions and specific pollution events. 
Acknowledgements. The authors thank their colleague Vito Summa for continuing support and discussions.

This work was carried out in the framework of the research agreement between Regione Basilicata - Osservatorio Ambientale della Val d'Agri and the Istituto di Metodologie per l'Analisi Ambientale of the National Research Council (CNR).

Edited by: V. Lapenna

Reviewed by: J. Dvarioniene and another anonymous referee

\section{References}

Alastuey, A., Querol, X., Rodriguez, S., Plana, F., Lopez-Soler, A., Ruiz, C., and Mantilla, E.: Monitoring of atmospheric particulate matter around sources of secondary inorganic aerosol, Atmos. Environ., 38, 4979-4992, 2004.

Alastuey, A., Querol, X., Castillo, S., Escudero, M., Avila, A., Cuevas, E., Torres, C., Romero, P. M., Exposito, F., García O., Diaz, J. P., Van Dingenen, R., and Putaud, J. P.: Characterisation of TSP and $\mathrm{PM}_{2.5}$ at Izaña and Sta. Cruz de Tenerife (Canary Islands, Spain) during a Saharan Dust Episode (July 2002), Atmos. Environ., 39, 4715-4728, 2005.

Aleksandropoulou, V. and Lazaridis, M.: Identification of the Influence of African Dust on $\mathrm{PM}_{10}$ Concentrations at the Athens Air Quality Monitoring Network during the Period 2001-2010, Aerosol Air Qual. Res., 13, 1492-1503, 2013.

Amato, F., Pandolfi, M., Escrig, A., Querol, X., Alastuey, A., Pey, J., Perez, N., and Hopke, P. K.: Quantifying road dust resuspension in urban environment by Multilinear Engine: a comparison with PMF2, Atmos. Environ., 43, 2770-2780, 2009.

Artiñano, B., Salvador, P., Alonso, D. G., Querol, X., and Alastuey, A.: Influence of traffic on the $\mathrm{PM}_{10}$ and $\mathrm{PM}_{2.5}$ urban aerosol fractions in Madrid (Spain), Sci. Total Environ., 334, 111-123, 2004.

Bell, S.: Measurement Good Practice Guide. A Beginner's Guide to Uncertainty of Measurement, Centre for Basic, Thermal and Length Metrology National Physical Laboratory, Teddington, Middlesex, UK, 1999.

Benn, D. I.: Fabric shape and the interpretation of sedimentary fabric data, J. Sediment. Res., 64, 910-915, 1994.

Cabada, J. C., Rees, S., Takahama, S., Khlystov, A., Pandis, S. N., Davidson, C. I., and Robinson, A. L.: Mass size distribution and size resolved chemical composition of fine particulate matter at the Pittsburgh supersite, Atmos. Environ., 38, 3127-3141, 2004.

Caggiano, R., Macchiato, M., and Trippetta, S.: Levels, chemical composition and sources of fine aerosol particles $\left(\mathrm{PM}_{1}\right)$ in an area of the Mediterranean basin, Sci. Total Environ., 408, 884895, 2010.

Campos-Ramos, A., Aragon-Pina, A., Alastuey, A., GalindoEstrada, I., and Querol, X.: Levels, composition and source apportionment of rural background $\mathrm{PM}_{10}$ in western Mexico (state of Colima), Atmos. Poll. Res., 2, 409-417, 2011.

Cheng, Y., Ho, K. F., Lee, S. C., and Law, S. W.: Seasonal and diurnal variations of $\mathrm{PM}_{1}, \mathrm{PM}_{2.5}$ and $\mathrm{PM}_{10}$ in the roadside environment of Hong Kong, China Particuol., 4, 312-315, 2006.

Chiari, M., Lucarelli, F., Mazzei, F., Nava, S., Paperetti, L., Prati, P., Valli, G., and Vecchi, R.: Characterization of airborne particulate matter in an industrial district near Florence by PIXE and PESA, X-Ray Spectrom., 34, 323-329, 2005.
Claiborn, C. S., Finn, D., Larson, T. V., and Koenig, J. Q.: Windblown dust contributes to high $\mathrm{PM}_{2.5}$ concentrations, J. Air Waste Manage., 50, 1440-1445, 2000.

Colbeck, I.: Environmental Chemistry of Aerosols, Blackwell Publishing Ltd, Oxford, UK, 2008.

Colbeck, I., Nasir, Z. A., Ahmad, S., and Ali, Z.: Exposure to $\mathrm{PM}_{10}$, $\mathrm{PM}_{2.5}, \mathrm{PM}_{1}$ and carbon monoxide on roads in Lahore, Pakistan, Aerosol Air Qual. Res., 11, 689-695, 2011.

Colette, A., Menut, L., Haeffelin, M., and Morille, Y.: Impact of the transport of aerosols from the free troposphere towards the boundary layer on the air quality in the Paris area, Atmos. Environ., 42, 390-402, 2008.

Giugliano, M., Lonati, G., Butelli, P., Romele, L., Tardivo, R., and Grosso, M.: Fine particulate $\left(\mathrm{PM}_{2.5}-\mathrm{PM}_{1}\right)$ at urban sites with different traffic exposure, Atmos. Environ., 39, 2421-2431, 2005.

Gomišček, B., Hauck, H., Stopper, S., and Preining, O.: Spatial and temporal variation of $\mathrm{PM}_{1}, \mathrm{PM}_{2.5}, \mathrm{PM}_{10}$ and particle number concentration during the AUPHEP-project, Atmos. Environ., 38, 3917-3934, 2004.

Graham, D. J. and Midgley, N. G.: Graphical representation of particle shape using triangular diagrams: an Excel spreadsheet method, Earth Surf. Proc. Land., 25, 1473-1477, 2000.

Haller, L., Claiborn, C., Larson, T., Koenig, J., Norris, G., and Edgar, R.: Airborne particulate matter size distributions in an arid urban area, J. Air Waste Manage., 49, 161-168, 1999.

Hieu, N. T. and Lee, B. K.: Characteristics of particulate matter and metals in the ambient air from a residential area in the largest industrial city in Korea, Atmos. Environ., 98, 526-5-37, 2010.

Illenberger, W. K.: Pebble shape (and size!), J. Sediment. Petrol., 61, 756-767, 1991.

IPCC: Climate Change 2007: The physical science basis, UK and New York, NY, USA, in: Contribution of Working Group I to the Fourth Assessment Report of the Intergovernmental Panel on Climate Change, edited by: Solomon S., Qin, D., Manning, M., Chen, Z., Marquis, M., Averyt, K. B., Tignor, M., and Miller, H. L., Cambridge University Press, Cambridge, 129-234, 2007.

Keywood, M. D., Ayers, G. P., Gras, J. L., Gillett, R. W., and Cohen, D. D.: Relationships between size segregated mass concentration data and ultrafine particle number concentration in urban areas, Atmos. Environ., 33, 2907-2913, 1999.

Klejnowski, K., Pastuszka, J. S., Rogula-Kozłowska, W., Talik, E., and Krasa, A.: Mass size distribution and chemical composition of the surface layer of summer and winter airborne particles in Zabrze, Poland, Bull. Environ. Contam. Toxicol., 88, 255-259, 2012.

Laakso, L., Hussein, T., Aarnio, P., Komppula, M., Hiltunen, V., Viisanen, Y., and Kulmala, M.: Diurnal and annual characteristics of particle mass and number concentrations in urban, rural and Arctic environments in Finland, Atmos. Environ., 37, 26292641, 2003.

Li, C.-S. and Lin, C.-H.: $\mathrm{PM}_{1} / \mathrm{PM}_{2.5} / \mathrm{PM}_{10}$ characteristic in the urban atmosphere of Taipei, Aerosol Sci. Tech., 36, 469-473, 2002.

Lin, J. and Lee, L. C.: Characterization of the concentration and distribution of urban submicron $\left(\mathrm{PM}_{1}\right)$ aerosol particles, Atmos. Environ., 38, 469-475, 2004. 
Lundgren, D. A., Hlaing, D. N., Thomas, A. R., and Marple, V. A.: $\mathrm{PM}_{10} / \mathrm{PM}_{2.5} / \mathrm{PM}_{1}$ data from a trichotomous sampler, Aerosol Sci. Tech., 25, 353-357, 1996.

Makkonen, U., Hellén, H., Anttila, P., and Ferm, M.: Size distribution and chemical composition of airborne particles in southeastern Finland during different seasons and wildfire episodes in 2006, Sci. Total Environ., 408, 644-651, 2010.

Massey, D., Kulshrestha, A., Masih, J., and Taneja, A.: Seasonal trends of $\mathrm{PM}_{10}, \mathrm{PM}_{5.0}, \mathrm{PM}_{2.5} \& \mathrm{PM}_{1.0}$ in indoor and outdoor environments of residential homes located in North-Central India, Build. Environ., 47, 223-231, 2012.

Pérez, N., Pey, J., Querol, X., Alastuey, A., López, J. M., and Viana, M.: Partitioning of major and trace components in $\mathrm{PM}_{10} / \mathrm{PM}_{2.5} / \mathrm{PM}_{1}$ at an urban site in Southern Europe, Atmos. Environ., 42, 1677-1691, 2008.

Pérez, N., Pey, J., Cusack, M., Reche, C., Querol, X., Alastuey, A., and Viana, M.: Variability of particles number, black carbon, and $\mathrm{PM}_{10}, \mathrm{PM}_{2.5}$ and $\mathrm{PM}_{1}$ levels and speciation: influence of road traffic emission on urban air quality, Aerosol Sci. Tech., 44, 487499, 2010

Pey, J., Pérez, N., Castillo, S., Viana, M., Moreno, T., Pandolfi, M., López-Sebastián, J. M., Alastuey, A., and Querol, X.: Geochemistry of regional background aerosols in the Western Mediterranean, Atmos. Environ., 94, 422-435, 2009.

Pey, J., Querol, X., and Alastuey, A.: Discriminating the regional and urban contributions in the North-Western Mediterranean: PM levels and composition, Atmos. Environ., 44, 1587-1596, 2010.

Pope III, C. A. and Dockery, D. W.: Health effects of fine particulate air pollution: lines that connect, J. Air Waste Manage. Assoc., 56, 709-742, 2006.

Putaud, J. P., Van Dingenen, R., and Raes, F.: Submicron aerosol mass balance at urban and semirural sites in the Milan area (Italy), J. Geophys. Res.-Atmos., 107, LOP 11-1-LOP 11-10, 2002.

Querol, X., Alastuey, A., Rodriguez, S., Plana, F., Ruiz, C. R., Cots, N., Guillem, M., and Puig, O.: $\mathrm{PM}_{10}$ and $\mathrm{PM}_{2.5}$ source apportionment in the Barcelona Metropolitan area, Catalonia, Spain, Atmos. Environ., 35, 6407-6419, 2001.

Rodríguez, S., Cuevas, E., González, Y., Ramos, R., Romero, P. M., Pérez, N., Querol, X., and Alastuey, A.: Influence of sea breeze circulation and road traffic emission on the relationship between particle number, black carbon, $\mathrm{PM}_{1}, \mathrm{PM}_{2.5}$ and $\mathrm{PM}_{2.5-10}$ concentrations in a coastal city, Atmos. Environ., 42, 6523-6534, 2008.

Shahsavani, A., Naddafi, K., Jafarzade Haghighifard, N., Mesdaghinia, A., Yunesian, M., Nabizadeh, R., Arahami, M., Sowlat, M. H., Yarahmadi, M., Saki, H., Alimohamadi, M., Nazmara, S., Motevalian, S. A., and Goudarzi, G.: The evaluation of $\mathrm{PM}_{10}$, $\mathrm{PM}_{2.5}$, and $\mathrm{PM}_{1}$ concentrations during the Middle Eastern Dust (MED) events in Ahvaz, Iran, from April through September 2010, J. Arid Environ., 77, 72-83, 2012.
Sneed, E. D. and Folk, R. L.: Pebbles in the lower Colorado River, Texas, a study in particle morphogenesis, J. Geol., 66, 114-150, 1958.

Spindler, G., Muller, K., Bruggemann, E., Gnauk, T., and Herrmann, H.: Long-term size-segregated characterization of $\mathrm{PM}_{10}$, $\mathrm{PM}_{2.5}$, and $\mathrm{PM}_{1}$ at the IfT research station Melpitz downwind of Leipzig (Germany) using high and low-volume filter samplers, Atmos. Environ., 38, 5333-5347, 2004.

Spindler, G., Brüggemann, E., Gnauk, T., Grüner, A., Müller, K., and Herrmann, H. A.: four-year size-segregated characterization study of particles $\mathrm{PM}_{10}, \mathrm{PM}_{2.5}$ and $\mathrm{PM}_{1}$ depending on air mass origin at Melpitz, Atmos. Environ., 44, 164-173, 2010.

Theodosi, C., Grivas, G., Zarmpas, P., Chaloulakou, A., and Mihalopoulos, N.: Mass and chemical composition of sizesegregated aerosols $\left(\mathrm{PM}_{1}, \mathrm{PM}_{2.5}, \mathrm{PM}_{10}\right)$ over Athens, Greece: local versus regional sources, Atmos. Chem. Phys., 11, 1189511911, doi:10.5194/acp-11-11895-2011, 2011.

Trippetta, S., Caggiano, R., and Telesca, L.: Analysis of particulate matter in anthropized areas characterized by the presence of crude oil pre-treatment plants: The case study of the Agri Valley (southern Italy), Atmos. Environ., 77, 105-116, 2013.

Vallius, M. J., Ruuskanen, J., Mirme, A., and Pekkanen, J.: Concentrations and estimated soot content of $\mathrm{PM}_{1}, \mathrm{PM}_{2.5}$, and $\mathrm{PM}_{10}$ in a subarctic urban atmosphere, Environ. Sci. Technol., 34, 19191925, 2000.

Van Dingenen, R., Raes, F., Putaud, J. P., Baltensperger, U., Charron, A., Facchini, M. C., Decesari, S., Fuzzi, S., Gehrig, R., Hansson, H. C., Harrison, R. M., Hüglin, C., Jones, A. M., Laj, P., Lorbeer, G., Maenhaut, W., Palmgren, F., Querol, X., Rodriguez, S., Schneider, J., ten Brink, H., Tunved, P., Tørseth, K., Wehner, B., Weingartner, E., Wiedensohler, A., and Wåhlin, P. A.: European aerosol phenomenology-1: physical characteristics of particulate matter at kerbside, urban, rural and background sites in Europe, Atmos. Environ., 38, 2561-2577, 2004.

Vecchi, R., Marcazzan, G., Valli, G., Ceriani, M., and Antoniazzi, C.: The role of atmospheric dispersion in the seasonal variation of $\mathrm{PM}_{1}$ and $\mathrm{PM}_{2.5}$ concentration and composition in the urban area of Milan (Italy), Atmos. Environ., 38, 4437-4446, 2004.

WHO: Health risks of particulate matter from long-range transboundary air pollution, Joint WHO/Convention Task Force on the Health Aspects of Air Pollution, WHO Regional Office for Europe, Copenhagen, 99 pp. 2006.

Wu, Y., Hao, J., Fu, L., Wang, Z., and Tang, U.: Vertical and horizontal profiles of airborne particulate matter near major roads in Macao, China, Atmos. Environ., 36, 4907-4918, 2002.

Yin, J. and Harrison, R. M.: Pragmatic mass closure study for $\mathrm{PM}_{1.0}, \mathrm{PM}_{2.5}$ and $\mathrm{PM}_{10}$ at roadside, urban background and rural sites, Atmos. Environ., 42, 980-988, 2008. 